\title{
Managing Shariah Non-Compliance Risk via Islamic Dispute Resolution
}

\author{
Maria Bhatti
}

Faculty of Law, Western Sydney University, Parramatta, NSW 2150, Australia; m.bhatti@westernsydney.edu.au

Received: 14 September 2019; Accepted: 12 December 2019; Published: 18 December 2019

\begin{abstract}
This article discusses Shariah non-compliance risk as a form of operational risk intending to ensure that operations in the Islamic and banking finance industry comply with Shariah procedures. In the field of Islamic finance, Shariah non-compliance risk refers to the possibility that Islamic finance transactions may be challenged based on Shariah non-compliance. This article uses a comparative and normative approach as well as a legal analysis of the case of Beximco. The article proposes the management of Shariah non-compliance risk by augmenting the effectiveness of Shariah governance systems with Islamic banking and finance arbitration; arbitration should be an enforced part of Islamic finance institutional arrangements—as it always has been classically—to provide flexibility for dispute resolution. To this end, the article examines contemporary implementations of Shariah arbitration rules to assess how Shariah non-compliance risk can be better managed via Islamic dispute resolution procedures.
\end{abstract}

Keywords: Shariah non-compliance risk; Islamic dispute resolution; i-arbitration rules; Shariah governance

\section{Introduction}

Managing Shariah non-compliance risk is vital to the establishment of an effective Shariah governance system. This article discusses Shariah non-compliance risk, namely the possibility that Islamic finance transactions can be challenged if they do not comply with Shariah. Due to the limited literature on the analysis of Shariah non-compliance risk using contemporary operational risk frameworks, this paper attempts to fill this gap by intending to ensure that operations in the Islamic banking and finance industry comply with fully regulated Shariah compliance processes. In particular, the article refers to scholarly views whereby Islamic banking and finance arbitration has been identified as an institutional framework which is essential to reducing Shariah non-compliance risk and upholding Shariah principles through compliance with proper Shariah governance practices (Ginena and Hamid 2015).

The recent growth of the Islamic finance industry has also increased the market demand for Shariah-compliant dispute resolution. Alternative dispute resolution is preferred over litigation because the former is flexible, private, efficient, neutral and provides parties with autonomy. International commercial arbitration is a method of international dispute resolution mechanism for international business disputes which allows parties to resolve their disputes with autonomy and flexibility. The methodology used in this article is a normative analysis and comparative approach, as well as a legal analysis of the case of Beximco to demonstrate the significance of effective dispute resolution procedures. The article compares existing Islamic dispute resolution mechanisms to examine the advantages and disadvantages of existing arbitration procedures, as well as providing reform proposals to Islamic dispute resolution procedures to better manage Shariah non-compliance risk. 


\section{What Is Shariah Non-Compliance Risk?}

The concept of risk takes a variety of forms depending on the discipline. Risk management refers to the procedure through which the exposure to risk is ascertained and managed. For example, in the discipline of finance, an example of risk is the potential of loss arising from activities of financial markets (Lahsasna 2014). Financial risks can also be further sub-categorised into reputational risk, operational risk and legal risk (Allen 2003). An example of business risk includes the risks companies take in order to increase competition and value (Lahsasna 2014). The potential risks outlined in the banking industry include market risk, credit risk, and operational risk (Ginena and Hamid 2015).

The Islamic Financial Services Board ('IFSB') provides standards for the Islamic banking and finance industry. In the Islamic banking and finance industry, six risks are outlined in a report published by the IFSB and titled, The Guiding Principles of Risk Management for Institutions (other than insurance institutions) Offering only Islamic Financial Services. These categories of risks include: credit risk, equity investment risk, market risk, liquidity risk, rate of return risk, and operational risk (Islamic Financial Services Board 2005). The relevant category for the purpose of this article is Shariah non-compliance risk which falls under operational risk. Principle 7.1 of the IFSB guidelines states that Islamic financial services ('IIFS') 'shall have in place adequate systems and controls, including a Shariah Board/Advisor, to ensure compliance with Shariah rules and principles' (Islamic Financial Services Board 2005). Shariah non-compliance risk falls under operational considerations and is relevant to ensure 'operations are executed in adherence to the applicable Shariah rules and principles as per the fatwa, policies and procedures approved by the IIFS's Shariah Board' (Islamic Financial Services Board 2005). Balz defines Shariah non-compliance risk as 'the chance that an Islamic financing transaction is challenged on grounds that it does not comply with Islamic law' (Balz 2008). Academics Ginena and Ahmed define Shariah-Risk as 'risk of financial losses that an Islamic financial institution may experience as a result of non-compliance in activities with Shariah precepts, as ascertained by the Shariah supervisory board or the pertinent authority in the relevant jurisdiction' (Ginena and Hamid 2015). Shariah non-compliance risk can also result in 'legal risk' being the failure to comply with contractual obligations and 'compliance risk', which is the risk of non-compliance with laws and regulations (Ginena and Hamid 2015).

An example of Shariah non-compliance risk could also include unenforceability of Shariah governing law clauses as well as Shariah non-compliance. For example, in the case of Beximco Pharmaceuticals Ltd \& Ors v. Shamil Bank of Bahrain EC. [2004] EWCA Civ 19. ${ }^{1}$, the agreement between the parties included a governing law clause, which stated, '[s]ubject to the principles of the Glorious Shariah, this Agreement shall be governed by and construed in accordance with the laws of England.' According to Shamil Bank, this would enable enforcement of the agreement under both English law and Shariah. However, Beximco argued that the finance agreements were invalid and not compliant with Shariah: 'it is uncontroversial that under Islamic law interest charged on loans by banks is [r]iba and prohibited. Equally, any agreement in which, in substance, interest is being charged upon a loan is unlawful, void and unenforceable' (Beximco). It was argued that the Islamic contract was labelled murabaha in form, but in fact interest was being charged and therefore, the contract was unenforceable (Beximco). The English Appellate Court ('the Appellate Court') decided that Shariah simply reflected the nature of the business, but did not apply as a legal system. English law applied in this case and therefore, it was not important for the Court to determine whether the subject matter was Shariah-compliant. According to Colon, the result of the Appellate Court's reasoning was that the words "[s]ubject to the principles of the Glorious Sharia'a" are rendered superfluous, but Shamil bank is still left to represent itself to its British customers as an "Islamic bank" (Colon 2011).

Two main forms of risk can be identified in this case:

1 Beximco Pharmaceuticals Ltd E Ors v. Shamil Bank of Bahrain EC. [2004] EWCA Civ 19. 
(1) Shariah non-compliance risk as it was argued that while the Islamic finance contract was labelled as murabaha, in substance the contract was similar to a standard conventional contract charging interest (riba);

(2) The risk that a Shariah governing clause may not be recognised and enforced in other jurisdictions.

This article will discuss how Islamic dispute resolution, as part of the Shariah governance system, can help address the risks identified.

\section{Shariah Governance and Islamic Dispute Resolution}

Shariah governance is a system through which Shariah non-compliance risk is assessed and it can consist of both internal and external bodies. For example, the Shariah board of the IIFS may be an internal mechanism through which Shariah products are audited for Shariah-compliance or an external audit may be the point of reference. Such institutional arrangements are crucial and include legal, regulatory, judicial and legislative mechanism through which Shariah non-compliance risk is addressed (Ginena and Hamid 2015; Hamza 2013). Shariah governance is significant to ensure that stakeholders have trust and confidence in the products offered, and that they are informed of the Shariah-compliant nature of the transactions (Ginena and Hamid 2015). One of the risks which have been identified within the Shariah governance system is the interpretation of Shariah by Islamic scholars either within the same Shariah board or across different Shariah boards (Ginena and Hamid 2015). The lack of standardization across Shariah scholars can lead to Shariah non-compliance risk because of the risk that a party may sue on the grounds that the product is not compliant with Shariah law as in the case of Beximco.

Experts have identified Islamic banking and finance arbitration as part of institutional arrangements which ensure effective Shariah governance and monitoring (Ginena and Hamid 2015; Hamza 2013). Therefore, it is necessary to explore Islamic banking and finance arbitration and in particular, the laws governing dispute resolution in this industry.

\section{Islamic Dispute Resolution}

Dispute resolution in Islamic jurisprudence has been discussed at length, a modern treatment of which is given by Rashid (2008): in a Shariah court, the judge is known as the qadi (literally, meaning to settle or resolve) who determines whether a dispute should be settled through șulh (negotiation, mediation), tahkim (arbitration) or administered in court. $S_{\text {ulh }}$, known as amicable settlement, conciliation or peacemaking was used in pre-Islamic Arabia where chieftains, soothsayers, healers and other influential noble men acted as arbiters and mediators in tribal disputes (Othman 2007).

During the Prophet Muhammad's time, the difference between șulh and tahkīm was evident because sulh was equivalent to modern day mediation where parties compromised or negotiated upon a peaceful settlement with the help of a third party. On the other hand, tahkim was similar to modern day arbitration where the third party made a binding decision and the arbitrator was someone who was well-versed in Islamic law (Othman 2007). There were, however, differences of opinion on the enforcement of the decisions made by arbitrators and depending on the Islamic schools of jurisprudence followed, arbitral decisions have different enforcement power (Kutty 2006).

Islamic finance disputes can either be resolved domestically through mediation or arbitration centres where domestic law applies. Alternatively, if the scope of the dispute is international (e.g., McMillen 2007), the disputes can be resolved through International Commercial Arbitration. Some conventions, treaties and rules governing the field of international commercial arbitration include the New York Convention of 1958, the United Nationals Commission on International Trade Law Arbitration Rules and the United Nationals Commission on International Trade Model Law on International Commercial Arbitration ('UNCITRAL Model Law'). However, Muslim countries have also kept up with trend of globalisation and established various arbitration centres such as the Euro-Arab Chambers of Commerce, Asian International Arbitration Centre, International Islamic Centre 
for Reconciliation and Arbitration, Cairo Regional Centre for International Commercial Arbitration, Abu Dhabi Commercial Conciliation and Arbitration Centre, and many more (Bhatti 2019).

This arbitration centres are critical to Shariah-compliant dispute resolution due to their readily recognising established Islamic commercial law rulings such as the prohibition of riba and gharar are contrary to Shariah as opposed to relying on (possibly subjective) stipulations of Shariah-compliance. For example, in Islamic dispute resolution, if an arbitrator or mediator determines the penalty for late payment, it cannot include riba. Similarly, if the subject matter of the dispute contains riba and/or gharar, the matter may not be arbitrable (Bhatti 2019). Furthermore, in Islamic dispute resolution, Shariah experts can be used as expert witnesses to determine matters relating to Islamic finance disputes. This way the mediator or arbitrator can be a qualified and registered dispute resolution practitioner, who can draw upon expert evidence from a Shariah expert. The issue then becomes how to effectively conduct Shariah-compliant dispute resolution. One of the main issues in the case Beximco was the lack of recognition of Islamic law as a comprehensive body of law which had the capacity to apply in a secular system. In light of this case, it is proposed that a comprehensive codified body of law be developed in the area of Islamic dispute resolution.

\section{Shariah-Compliant Arbitration Rules}

Interestingly, there have been attempts to develop Shariah-compliant arbitration rules appropriate for in the modern world. For example, those published by the International Islamic Centre for Reconciliation and Arbitration ('IICRA') (IICRA 2007). Arbitration guidelines have also been developed by the Accounting and Auditing Organization for Islamic Finance Institutions ('AAOIFI') known as AAOIFI Standard No. 32. However, the most developed of the Shariah-compliant arbitration rules have been developed by the Asian International Arbitration Centre ('AIAC') known as the i-Arbitration Rules. The aim of the i-Arbitration Rules is to accommodate Shariah-based disputes because they provide a procedure whereby arbitral tribunals refer matters to Shariah advisory councils (Global Arbitration Review 2009). Sundra Rajoo, Director of AIAC, notes:

"With the advent of globalisation and increasing cross-border transactions, the centre decided to come up with a set of rules that provide for international commercial arbitration that is suitable for commercial transactions premised on Islamic principles, and that would be recognised and enforceable internationally. Many Asian arbitration centres have their niche-for example, Hong Kong is an obvious venue for China-related disputes, and as a plural society with a majority of Muslim citizens and a regional hub for Islamic finance, Malaysia could be an appealing neutral arbitration forum for parties who have issues with Shariah contracts." (Global Arbitration Review)

There are various reasons why the i-Arbitration Rules are more developed than the AAOIFI Arbitration Standards and the IICRA rules. For example, the IICRA rules rely on the arbitral tribunal only for their Shariah expertise, which is suitable for domestic disputes but not for more complex international disputes (IICRA 2007). On the other hand, the i-Arbitration Rules provide more detailed rules in relation to expert evidence allowing the procedural process to be more consistent with United Nations Commission on International Trade Law Arbitration Rules 2010 ('UNCITRAL Rules') (Bhatti 2019). Unfortunately, the AAOIFI Guidelines on arbitration do not delve into much detail about arbitration procedures and simply provide a very short reference to Islamic arbitration.

The i-Arbitration Rules are also more developed in relation to matters such as penalties for late payment (gharamah) and compensation ( $\left.t a^{\prime} w i d h\right)$. They refer to the Islamic money market set up by the Bank Negara Malaysia as a reference when calculating the rate of profit awarded, as opposed to conventional interest rates. Gharamah is an Arabic term defined as the penalty for late payment, and $t a^{\prime}$ widh means compensation for late payment (Securities Commission Malaysia 2004). The reason why the SAC considers compensation or ' $t a$ ' $w i d h$ ' Shariah compliant is based on the saying of the Prophet Muhammad that '[p]rocrastination (delay) in repaying debts by a wealthy person is injustice' 
(Muhsin Khan 2019). The Shariah resolution by the Shariah Advisory Council of Bank Negara Malaysia also states that the '[i]slamic financial institution may recognise ta'widh as income on the basis that it is charged as compensation for actual loss suffered by the institution' (Bank Negara Malaysia 2010a). In the context of arbitration or judgment debts, the SAC notes that a '[c]ourt may impose late payment charge at the rate as stipulated by the procedures of court. However, from this rate, the judgment creditor (Islamic financial institution) is only allowed to receive compensation rate for actual loss (ta'widh)' (Bank Negara Malaysia 2010a; Bhatti 2019).

The i-Arbitration Rules contain a provision under Rule 12(8) noting the following in relation to the award of interest:

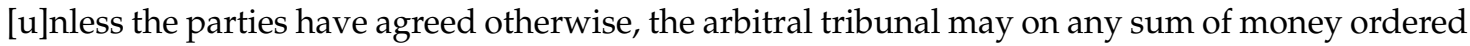
to be paid by the award on the whole or any part of the period between the date on which the cause of action arose and to the date of realisation of the award:

(a) Award a late payment charge determined by applying the principles of ta'widh and gharamah, where ta'widh refers to compensation or actual loss and gharamah refers to penalty for late payment; or

(b) In any other way that the arbitral tribunal considers appropriate, including interest.

Consequently, an arbitral tribunal may award a late payment charge as per Rule 12(8)(a) of the i-Arbitration Rules as compensation for actual loss suffered by the aggrieved party. The SAC notes that ' $[\mathrm{t}$ ] determine the compensation rate for actual loss ( $t a$ ' $w i d h)$ that may be applied by the judgment creditor, the SAC agreed to adopt the weighted average overnight rate of Islamic money market as a reference; and...[t]he total compensation charge shall not exceed the principal amount of debt. If the actual loss is less than the applicable rate for judgment in current practice, the balance shall be channeled [sic] by judgment creditor to charitable organisation as may be determined by Bank Negara Malaysia' (Bank Negara Malaysia 2010b).

$T a^{\prime}$ widh, as stipulated by the SAC, differs from the view of Islamic scholars such as Taqi Usmani, and scholars from the Islamic Fiqh Academy in Jeddah who argues that compensation is the same as interest. Mufti Taqi Usmani who argues 'there is no material difference between interest and the late payment [fee] charged as compensation' (Usmani 2002). Usmani argues that in practice, the additional amount charged in the name of compensation is riba, because Islam does not allow for aggrieved parties to claim additional amounts from the debtor (Usmani 2002). However, he argues that a penalty may be issued against the defaulting party, but the penalty amount is not compensation for the loss suffered by a party due to the lost opportunity of investing the money (Usmani 2002). Usmani proposes that in order to prevent parties from defaulting, the defaulting party should pay the penalty to a charitable fund established by the bank or institution. He argues that this approach is based on the principles established under the Maliki school of thought, and the proper wording of the penalty clause should be as follows:

The client hereby undertakes that if he defaults in payment of any of his dues under this agreement, he shall pay to the charitable account/fund maintained by the Bank/financier a sum calculated on the basis of ... \% per annum for each day of default unless he establishes through the evidence satisfactory to the Bank/financier that his non-payment at the due date was caused due to poverty or some other factors beyond his control (Usmani 2002).

Since Taqi Usmani is also the chairman of the Shariah board of the AAOIFI, this approach is taken by the AAOIFI under Standard No. 8 on murabaha, which also stipulates that the penalty should be given in charity, as per the following clause:

It is permissible that the contract of [m] urabaha consists of an undertaking from the customer to pay an amount of money or a percentage of the debt, on the basis of undertaking to donate it in the event of a delay on his part in paying instalments on their due date. The Shariah Supervisory 
Board of the [i]nstitution [AAOIFI] must have full knowledge that any such amount is indeed spent on charitable causes, and not for the benefit of the [i]nstitution [AAAOIFI] itself (Accounting and Auditing Organization for Islamic Financial Institutions AAOIFI).

Similarly, the State Bank of Pakistan notes that:

[i]t can be stipulated while entering into the agreement that in case of late payment or default by the client he shall be liable to pay penalty calculated at percent per day or per annum that will go to the charity fund constituted by the bank... The bank can also approach competent courts for award of solatium which shall be determined by the courts at their discretion, on the basis of direct and indirect costs incurred, other than opportunity cost (State Bank of Pakistan Islamic Banking Department 2015).

According to the Islamic Fiqh Academy in Jeddah, '[i]f the buyer/debtor delays the payment of instalments after the specified date, it is not permissible to charge any amount in addition to its principle liability, whether it is made a precondition in the contract or it is claimed without a previous agreement, because it is "[r]iba", hence prohibited in Shariah" (State Bank of Pakistan Islamic Banking Department 2015). Although penalty provisions may be included in financial contracts, if the penalty is in relation to a debt, then that is characterized as ' $r i b a^{\prime}$ (State Bank of Pakistan Islamic Banking Department 2015). This is due to the Qur'anic verse: '[i]f the debtor is in difficulty, then delay things until matters become easier for him; still, if you were to write it off as an act of charity, that would be better for you, if only you knew' (The Qur'an, Chap. 2, Verse 280).

On the other hand, this issue has been elaborated on by the Shariah Advisory Council of Bank Negara Malaysia ("SAC") because in several meetings, the SAC has ruled that a defaulting party may be charged a penalty under the principle of 'gharamah', and that the proceeds 'shall not be recognised as income. Instead, it has to be channelled to certain charitable bodies' (Securities Commission Malaysia 2002-2014).

Table 1 below outlines advantages and disadvantages of each Shariah arbitration rule, and potential Shariah-risk management proposals. 
Table 1. Comparative Chart for Codified Islamic Finance Dispute Resolution Procedures.

\begin{tabular}{|c|c|c|c|}
\hline Rules & Advantages & Disadvantages & Reform Proposals \\
\hline $\begin{array}{l}\text { AAOIFI Standard No. } 32 \text { on } \\
\text { Arbitration }\end{array}$ & $\begin{array}{l}\text { AAOIFI standards provide credibility as } \\
\text { it is a reputable organization. } \\
\text { Consists of international Shariah } \\
\text { scholars, who are well known in the } \\
\text { Islamic finance industry. } \\
\text { Harmonizes Islamic finance standards. }\end{array}$ & $\begin{array}{l}\text { Does not comprehensively address arbitration } \\
\text { procedures. } \\
\text { Shariah scholars may follow a certain } \\
\text { interpretation of Islamic law. } \\
\text { Arbitration standards are not consistent with } \\
\text { UNCITRAL Rules. }\end{array}$ & $\begin{array}{l}\text { Comprehensive development of } \\
\text { arbitration procedures are required. } \\
\text { Address how differences amongst } \\
\text { Shariah scholars will be resolved. }\end{array}$ \\
\hline IICRA Rules on Arbitration & $\begin{array}{l}\text { IICRA is one of the few specialised } \\
\text { Islamic arbitration institutions. } \\
\text { IICRA is one of the few institutions that } \\
\text { has developed Islamic arbitration rules. }\end{array}$ & $\begin{array}{l}\text { Arbitration procedures are more suitable to } \\
\text { local UAE disputes. } \\
\text { Arbitration standards are not consistent with } \\
\text { UNCITRAL Rules. }\end{array}$ & $\begin{array}{l}\text { Further development of arbitration } \\
\text { procedures which are consistent } \\
\text { UNCITRAL Rules are required. } \\
\text { IICRA needs to provide a more } \\
\text { transparent service, including a } \\
\text { well-developed website and ensuring } \\
\text { IICRA members are contactable for } \\
\text { further research and collaboration } \\
\text { opportunities. }\end{array}$ \\
\hline i-Arbitration Rules & $\begin{array}{l}\text { AAIC is an internationally reputable } \\
\text { organisation. } \\
\text { The i-Arbitration Rules cater for Shariah } \\
\text { principles as well as international rules } \\
\text { such as the UNCITRAL Rules. } \\
\text { The i-Arbitration Rules are } \\
\text { comprehensive, well-developed and } \\
\text { cater for international disputes. }\end{array}$ & $\begin{array}{l}\text { The i-Arbitration rules provide the tribunal } \\
\text { with the power to award interest if agreed by } \\
\text { the parties, which may be viewed as } \\
\text { non-compliant with Shariah. } \\
\text { The i-Arbitration rules need to clarify its } \\
\text { position in relation to the arbitrability of } \\
\text { disputes which contain riba and/or gharar. }\end{array}$ & $\begin{array}{l}\text { Further development required in the } \\
\text { area of arbitrability of non-Shariah } \\
\text { compliant subject matters. } \\
\text { Arbitral procedures in relation to expert } \\
\text { evidence need to be further developed. } \\
\text { Different approaches to } t a^{\prime} w i d h \text { and } \\
\text { gharamah needs to be addressed. }\end{array}$ \\
\hline
\end{tabular}


Therefore, based on Table 1, the advantages listed for the i-Arbitration Rules indicate that subject to further reforms in the area of expert evidence rules and arbitrability, the i-Arbitration Rules, as developed by the AIAC, are the most comprehensive dispute resolution rules. Furthermore, these rules can be amended as agreed between the parties due to the concept of party autonomy in private international law. Redfern and Hunter state that '[i]t is generally recognised that parties to an international commercial agreement are free to choose for themselves the law (or the legal rules) applicable to that agreement. The doctrine of party autonomy, which was first developed by academic writers and then adopted by national courts, has gained extensive acceptance in national systems of law.' (Blackaby et al. 2015).

As per the concept of party autonomy, parties have the right to choose Shariah as their governing law and is one of the main advantages of private arbitration as well as striving to provide a neutral and flexible dispute resolution process (Garnett et al. 2000).

\section{Concluding Remarks}

This article uses a comparative and normative approach to discuss the significance of Islamic banking and finance arbitration as part of institutional arrangements in order to ensure effective Shariah governance. Such institutional arrangements are crucial to address Shariah non-compliance risk. It is for this reason that international Islamic institutions need to develop comprehensive and internationally recognized Islamic dispute resolution procedures.

Funding: This research received no external funding.

Conflicts of Interest: The authors declare no conflict of interest.

\section{References and Note}

Accounting and Auditing Organization for Islamic Financial Institutions (AAOIFI). 2015. Shari'ah Standards. Manama: AAOIFI.

Allen, Steve. 2003. Financial Risk Management: A Practitioner's Guide to Managing Market. Hoboken: Wiley \& Sons. Balz, Kilian. 2008. Sharia Risk? How Islamic Finance Has Transformed Islamic Contract Law. Cambridge: Occasional Publications; Harvard Law School, Islamic Legal Studies Program, p. 9.

Bank Negara Malaysia. 2010a. SAC 4th Meeting on 14 February 1998, 95th Meeting on 28 January 2010 and 101 st Meeting on 20 May 2010. Available online: http://www.sacbnm.org/wp-content/uploads/2018/03/81.E.pdf (accessed on 1 August 2019).

Bank Negara Malaysia. 2010b. Shariah Resolutions in Islamic Finance; Kuala Lumpur: Central Bank of Malaysia. Bhatti, Maria. 2019. Islamic Law and International Commercial Arbitration. New York: Routledge.

Blackaby, Nigel, Constantine Partasides, Alan Redfern, and Martin Hunter. 2015. Redfern and Hunter on International Arbitration, 6th ed. Oxford: Oxford University Press.

Colon, Julio. 2011. Choice of Law and Islamic Finance. Texas International Law Journal 46: 411.

Garnett, Richard, Henry Gabriel, Jeffrey Waincymer, and Judd Epstein. 2000. A Practical Guide to International Commercial Arbitration. New York: Oceana Publications.

Ginena, Karim, and Azhar Hamid. 2015. Foundations of Shariah Governance of Islamic Banks. West Sussex: John Wiley \& Sons.

Global Arbitration Review. 2009. KLRCA to Unveil Islamic Arbitration Rules. Available online: http://globalarbitrationreview.com/article/1031606/klrca-to-unveil-islamic-arbitration-rules (accessed on 1 September 2019).

Hamza, Hichem. 2013. Sharia Governance in Islamic Banks: Effectiveness and Supervision Model. International Journal of Islamic and Middle Eastern Finance and Management 6: 226. [CrossRef]

IICRA. 2007. Chart and Arbitration and Reconciliation Procedures. Available online: iicra.com (accessed on 1 August 2019).

Islamic Financial Services Board. 2005. The Guiding Principles of Risk. Available online: www.ifsb.org (accessed on 1 July 2019). 
Kutty, Faisal. 2006. Shari'a in International Commercial Arbitration. The Loyola of Los Angeles International and Comparative Law Review 28: 564-90.

Lahsasna, Ahcene. 2014. Shariah Non-Compliance Risk Management and Legal Documentations in Islamic Finance. New York: John Wiley \& Sons.

McMillen, Michael J. T. 2007. Contractual Enforceability Issues: Sukuk and Capital Markets Development. Chicago Journal of International Law 7: 427-67.

Othman, Aida. 2007. And Amicable Settlement is Best: Sulh and Dispute Resolution in Islamic Law. Arab Law Quarterly 21: 64-68. [CrossRef]

Rashid, Syed Khalid. 2008. Peculiarities \& Religious Underlining of ADR in Islamic Law. In Mediation in the Asia Pacific: Constraints and Challenges. Kuala Lumpur: International Islamic University Malaysia.

Muhsin Khan, Muhammad. 2019. Sahih al-Bukhari. Loans, Payment of Loans, Freezing of Property, Bankruptcy. Available online: www.sunnah.com (accessed on 1 June 2019).

Securities Commission Malaysia. 2002-2014. Resolutions of the Shariah Advisory Council of the Securities Commission Malaysia. Kuala Lumpur: Securities Commission Malaysia.

Securities Commission Malaysia. 2004. Resolutions of the Securities Commission Shariah Advisory Council. Kuala Lumpur: Securities Commission Malaysia.

State Bank of Pakistan Islamic Banking Department. 2015. Essentials of Islamic Modes of Financing. State Bank of Pakistan. Available online: www.sbp.org.pk/press/2004/Islamic_modes.pdf (accessed on 1 June 2019).

Usmani, Muhammad Taqi. 2002. An Introduction to Islamic Finance. Netherlands: Kluwer Law International.

(C) 2019 by the author. Licensee MDPI, Basel, Switzerland. This article is an open access article distributed under the terms and conditions of the Creative Commons Attribution (CC BY) license (http://creativecommons.org/licenses/by/4.0/). 